\title{
FACTORS AFFECTING THE PREVENTION OF CORRUPTION USING FRAUD HEPTAGON APPROACH
}

\author{
Hendi Prihanto* \\ Faculty of Business and Economy, Universitas Prof. Dr. Moestopo (Beragama) \\ *Correspondence: hendiprihanto@dsn.moestopo.ac.id
}

$\begin{array}{ll}\text { ARTICLE INFO } & \text { ABSTRACT } \\ \text { Article History: } & \begin{array}{l}\text { This study aims to obtain evidence of the factors affecting the } \\ \text { prevention of corruption in Indonesia by using the fraud Heptagon } \\ \text { received: } 09 / 11 / 2020\end{array} \\ \text { approach by analyzing the factors causing corruption through } \\ \text { accepted: } 09 / 02 / 2021 & \begin{array}{l}\text { organizational culture, leadership, code of ethics, information } \\ \text { technology, and governance as intervening variables. The } \\ \text { population of the study is government agencies such as ministries, }\end{array} \\ \text { Keywords: } & \begin{array}{l}\text { high state institutions, local governments, and other government } \\ \text { organizations, obtained randomly through several activities of } \\ \text { grganizational Culture; } \\ \text { Leadership; Code of ethics; } \\ \text { Corruption; Governance. }\end{array} \\ \text { using google form and paper-based questionnaires. The results of } \\ \text { the study show that information technology has a direct and } \\ \text { significant effect on preventing corruption, while organizational } \\ \text { culture and code of ethics has a significant indirect effect on good } \\ \text { governance. }\end{array}$

\section{INTRODUCTION}

Corruption is behavior deviating from official duties in state administration to obtain benefits related to status and wealth either for personal self, close family, or group that violates the rules (Klitgaard, 2001). Corruption is divided into two types, namely: a) corruption due to conflicts of interest, and b) bribes and illegal grants. Corrupt behavior is mostly identical to state officials with high position and income (Tuanakotta, 2007). Consequently, leaders as officials who administer state affairs are less trustworthy and accountable in carrying out their duties (Prihanto and Gunawan, 2020; Prihanto et al., 2020). In fact, as government officials, they are supposed to have an anti-corruption attitude (Ndraha, 2007). Quoted from kompas.com, the monitoring carried out by ICW from January 1 to June 30, 2020 discovers approximately 169 corruption cases with 372 suspects from government officials leading to a state loss of IDR 18.1 trillion (Mashabi, 2020), the types of which are varied, such as the procurement of goods and services (Corruption Eradication Commission, 2018) in the form of gratification between the parties participating in tenders and the officials from institutions procuring the goods and services (Prihanto and Usmar, 2020).

The government should aim for prosperity and freedom from corruption for its people (Ndraha, 2007), yet the administration of state affairs is highly vulnerable to conflicts of interest (Jensen and Meckling, 1976b) that has the potential to cause information asymmetry (Fama et al., 2007), resulting in a culture of corruption that greatly impacts governance and antifraud control to eradicate corruption (Bierstaker, 2009). A good culture has a significant positive relationship with 
governance and the risk of fraud (Mihret, 2015; Wahab, Pitchay and Ali, 2016), associated with the presence of effective leaders. Furthermore, women leaders are capable of suppressing corruption (Lenard et al., 2017) and reducing the number of fraud (Prabowo et al., 2017) by implementing good governance and code of ethics (Law, 2011; Mensah and Zutter, 2017). Therefore, a well-implemented code of ethics ensures that the organization is protected from fraud (Siregar and Tenoyo, 2015). It will be more effective supposing it is implemented with governance based on information technology that assists in detecting and preventing fraud (Halbouni, Obeid and Garbou, 2016a). This study aims to analyze the effect of organizational culture, leadership, code of ethics, IT, and governance on the prevention of corruption by the State Civil Apparatus managing state affairs in government institutions in Indonesia.

METHOD

Measurement of Variables and
Hypotheses

The variables were measured using a 5-point Likert scale. Corruption was measured by Fraud Heptagon (Yusof, 2016), namely: incentive, pressure, opportunity, attitude, rationalization, ability or competence, arrogance, ignorance, and greed. Organizational culture (Robbins and Coulter, 2012) consists of: innovation and risk-taking, attention to detail, outcome orientation, human orientation, team orientation, aggressiveness, and stability. Effective leadership (Wolf and Shelton, 2015) comprises: Bring people together with work as a team, Motivate people to perform, Take responsibility for bottom-line result, Make difficult decision, and Create positive energy. The code of ethics (Law No. 5 on Public Accountants, 2011) includes: responsibility, emphasis on public interests, integrity, objectivity, competence and prudence, confidentiality, professional behavior, and technical standards. Information technology (Fung Jin, 2003) is comprised of: social factors, affectivity, complexity, task suitability, long-term consequences, and conditions facilitating the use of information technology. Meanwhile, governance (FCGI, 2001) (FCGI, 2001) has the following criteria: participation, legal certainty, responsibility, consensus, justice, effectiveness and efficiency, as well as vision and mission. The hypotheses in this study are as follows:

Table 1. hypotheses and description

\begin{tabular}{|c|c|}
\hline Criteria & Amount \\
\hline $\mathrm{H} 1$ & $\begin{array}{l}\text { Organizational culture has a positive } \\
\text { effect on reducing corrupt behavior }\end{array}$ \\
\hline $\mathrm{H} 1 \mathrm{a}$ & $\begin{array}{l}\text { Organizational culture has a positive } \\
\text { effect on good governance }\end{array}$ \\
\hline $\mathrm{H} 2$ & $\begin{array}{l}\text { Effective leadership has a positive } \\
\text { effect on reducing corrupt behavior }\end{array}$ \\
\hline $\mathrm{H} 2 \mathrm{a}$ & $\begin{array}{l}\text { Effective leadership has a positive } \\
\text { effect on good governance }\end{array}$ \\
\hline H3 & $\begin{array}{l}\text { Well-implemented code of ethics has a } \\
\text { positive effect on reducing corrupt } \\
\text { behavior }\end{array}$ \\
\hline H3a & $\begin{array}{l}\text { Well-implemented code of ethics has a } \\
\text { positive effect on good governance }\end{array}$ \\
\hline $\mathrm{H} 4$ & $\begin{array}{l}\text { Information technology has a positive } \\
\text { effect on reducing corrupt behavior }\end{array}$ \\
\hline $\mathrm{H} 4 \mathrm{a}$ & $\begin{array}{l}\text { Information technology has a positive } \\
\text { effect on good governance }\end{array}$ \\
\hline H5 & $\begin{array}{l}\text { Good governance has a positive effect } \\
\text { on reducing corrupt behavior }\end{array}$ \\
\hline
\end{tabular}

Source: analyzed by author, 2021

\section{RESULT AND DISCUSSION}

Hypothesis testing is presented in table 1 as follows: 


\begin{tabular}{|c|c|c|c|c|c|}
\hline \multicolumn{6}{|c|}{$\begin{array}{c}\mathrm{Kor}=\beta 0+\mathrm{BO}_{1}+\mathrm{KEP}_{2}+\mathrm{KE}_{3}+\mathrm{TI}_{4}+\mathrm{GG}_{5}+\mathrm{e} \\
\mathrm{GG}=\beta 0+\mathrm{BO}_{6}+\mathrm{KEP}_{7}+\mathrm{KE}_{8}+\mathrm{TI}_{9}+\mathrm{e}\end{array}$} \\
\hline Variable & Prediction & Koef. & P-Val. & Sig. & Description \\
\hline Direct effect: & \multicolumn{5}{|c|}{$\mathrm{Kor}=\beta \mathrm{o}-0.19 \mathrm{BO}_{1}+0.09 \mathrm{KEP}_{2}-0.36 \mathrm{KE}_{3}+0.85 \mathrm{TI}_{4}+0.11 \mathrm{GG}_{5}+0.65 \mathrm{e}$} \\
\hline $\mathrm{BO} \rightarrow \mathrm{KOR}$ & $\mathrm{H} 1(+)$ & -0.19 & -0.51 & Insig. & $\mathrm{H} 1$ is rejected \\
\hline $\mathrm{KEP} \rightarrow \mathrm{KOR}$ & $\mathrm{H} 2(+)$ & 0.09 & 0.52 & Insig. & $\mathrm{H} 2$ is rejected \\
\hline $\mathrm{KE} \rightarrow \mathrm{KOR}$ & $\mathrm{H} 3(+)$ & -0.36 & -1.03 & Insig. & $\mathrm{H} 3$ is rejected \\
\hline $\mathrm{TI} \rightarrow \mathrm{KOR}$ & $\mathrm{H} 4(+)$ & 0.85 & 2.33 & Sig. $* * *$ & $\mathrm{H} 4$ is accepted \\
\hline $\mathrm{GG} \rightarrow \mathrm{KOR}$ & $\mathrm{H} 5(+)$ & 0.11 & 0.29 & Insig. & $\mathrm{H} 5$ is rejected \\
\hline Indirect effect: & \multicolumn{5}{|c|}{$\mathrm{GG}=\beta 0+0.80 \mathrm{BO}_{6}+0.01 \mathrm{KEP}_{7}+0.52 \mathrm{KE}_{8}-1.45 \mathrm{TI}_{9}+0.21 \mathrm{e}$} \\
\hline $\mathrm{BO} \rightarrow \mathrm{GG}$ & $\mathrm{H} 1 \mathrm{a}(+)$ & 0.80 & 4.25 & Sig.**** & $\mathrm{H} 1 \mathrm{a}$ is accepted \\
\hline $\mathrm{KEP} \rightarrow \mathrm{GG}$ & $\mathrm{H} 2 \mathrm{a}(+)$ & 0.01 & 0.05 & Insig. & $\mathrm{H} 2 \mathrm{a}$ is rejected \\
\hline $\mathrm{KE} \rightarrow \mathrm{GG}$ & $\mathrm{H} 3 \mathrm{a}(+)$ & 0.52 & 2.51 & Sig.*** & H3a is accepted \\
\hline $\mathrm{TI} \rightarrow \mathrm{GG}$ & $\mathrm{H} 4 \mathrm{a}(+)$ & -0.32 & -1.45 & Insig. & $\mathrm{H} 4 \mathrm{a}$ is rejected \\
\hline$R^{2}(1-2)$ & \multicolumn{5}{|l|}{$0.35-0.79$} \\
\hline Error $(1-2)$ & \multicolumn{5}{|l|}{$0.65-0.21$} \\
\hline$P$ value & \multicolumn{5}{|l|}{$1.0000-1.0000$} \\
\hline Chi-Square & \multicolumn{5}{|l|}{0.389} \\
\hline RMSEA & \multicolumn{3}{|l|}{$0.000-0.000$} & & Fit \\
\hline $\mathrm{df}(1-2)$ & \multicolumn{5}{|l|}{614} \\
\hline The level of & $s^{*}=0.05$, & $=$ & 0.0 & f 2020 & tions \\
\hline
\end{tabular}

Source: analyzed by author, 2021.

\section{The effect of organizational culture on corruption and governance}

The results of the hypothesis testing show that organizational culture has no effect on corruption prevention, thus $\mathrm{H} 1$ is rejected. It is not in line with previous studies stating that organizational culture can reduce fraudulent behavior (Akbar and Vujić, 2014; Mihret, 2014; Quah, 2015). Organizational culture in government institutions remains unable to reduce corruption due to an informal culture affecting corruption (Yeganeh, 2014a; Loosemore and Lim, 2015). Yusof, (2016) states that corruption can be influenced by local culture that later affects organizational culture. The local culture of the community is also practiced in organizational life because officials are also part of the community. Local culture should strengthen the implementation of positive behavior (Quah, 2015) and become an antidote to the negative currents of competition that have the potential to raise the values that lead to corruption (Yeganeh, 2014b). Corruption can be prevented by fostering a culture of shame (Prabowo and Suhernita, 2017) to produce an attitude of high integrity (Umar, 2016; Sow et al., 2018).
A good and quality organizational culture has a positive and significant effect on the implementation of good governance in government organizations (Bierstaker, 2009; Bhasin, 2012; Mihret, 2014; Quah, 2015; Umar, 2016; Wahab, Pitchay and Ali, 2016), thus H1a is accepted. It is in line with previous studies. The improvement in the quality of good governance is evident from the innovation in organizational culture, such as discipline in work attendance, work commitment, sanctions for violations at work, the 5R culture (Concise, Neat, Clean, Caring, and Diligent), culture of togetherness, transparency, and integrity through wealth reporting (Prihanto et al., 2020). Organizational culture that adopts change initiatives such as communication, feedback, involvement, and consultation to achieve the vision and mission is essential for organizational success (Jumbe and Proches, 2017).

\section{The effect of leadership on corruption and governance}

The results of the study state that leadership has no significant effect on the reduction in corruption behavior, thus $\mathrm{H} 2$ is rejected. Leadership has a role in corruption, resulting from conflicts of interest (Jensen 
and Meckling, 1976a; Politis and Politis, 2018), either personal or group. Leadership has not been able to support the reduction of corruption and in fact tends to become the perpetrators of corruption due to low income or economic factors (Omar, Nawawi and Salin, 2016), Such leadership does not have high integrity (Chen et al., 2013; Umar, 2016). Not only because of the opportunity, capability, rationalization, competence, arrogance, and pressure (Yusof, 2016) frequently found in government institutions, corruption can also occur due to the behavior of highly educated and economically sufficient yet acquisitive leadership (Tuanakotta, 2007). Thus, we need leadership whose base their behavior on the code of ethics (Lee, 2017), capable of influencing their subordinates to behave similarly (Steinbauer et al., 2013). Leadership in Indonesia frequently experiences problems related to corruption due to conflicts of interest (Prihanto et al., 2020). In fact, as government officials, the leadership is supposed to have an anticorruption attitude and bring their citizens to prosperity (Ndraha, 2007). Leadership of government organization who has a political party background has the potential to be involved in corruption because they frequently involve the interests of their party in their work (Jensen and Meckling, 1976b), actually adding to the bad image of the party (Sudarsa, 2019) that should be able to promote accountability (Klitgaard, 2001) in the administration of government affairs.

The results also show that leadership is not entirely effective in creating good governance, thus $\mathrm{H} 2 \mathrm{a}$ is rejected. Approximately 60 percent of governance problems in Indonesia occurs due to government errors, leading them to be confined in their own rules (Madril, 2020). Therefore, it is necessary to have the support of good quality management (Brown et al., 2014) to create effective leadership. Ethical behavior in governance (Schwella, 2014) contributes to creating good governance (Ferry and Ahrens, 2016) with a fair and trustworthy attitude (Hamid et al., 2011). Leadership as a role model is inseparable from the implementation of governance, as both are conditions required by organizations to further achieve organizational goals in the future.

\section{The effect of code of ethics on corruption and governance}

The code of ethics has not been able to prevent corruption because it is not wellimplemented, thus $\mathrm{H} 3$ is rejected. It is not in line with the statement that wellimplemented code of ethics prevents unethical behavior (Siregar and Tenoyo, 2015; Nor, Nawawi and Salin, 2018) and is able to prevent corruption (Husnin, Nawawi and Salin, 2016). Thus, the code of ethics in government institutions that has not been well-implemented allows fraud to occur more easily through rationalization (Cressey, 1965; Wolfe and Hermanson, 2004; Crowe, 2011; Free and Murphy, 2015; Umar, 2016; Yusof, 2016; Vousinas, 2019). It is highly dangerous since it causes damage and destruction to the organization (Khadijah, Kamaluddin and Salin, 2015) as happened in the case of buying and selling opinions (Rozie, 2017), proving that the independence of the professional code of ethics as an auditor is violated.

The results of data processing reveal that code of ethics has a positive effect on good governance in Indonesia, thus $\mathrm{H3a}$ is accepted. Therefore, well-implemented code of ethics and commitment can achieve good governance (Asmuni, Nawawi and Salin, 2015; Omar, Nawawi and Salin, 2016; Zakaria, Anuar and Salin, 2016; Rahim, Nawawi and Salin, 2017; Nor, Nawawi and Salin, 2018), but can also prevent fraud (Rivest and Lanoue, 2015; Said et al., 2017), guiding officials to behave ethically inside and outside the organization (Kaptein and Schwartz, 2008). The code of ethics in realizing good governance has been implemented gradually in Indonesia to achieve better governance. 


\section{The effect of information technology on corruption and governance}

The results prove that information technology has a positive effect on reducing corrupt behavior, thus $\mathrm{H} 4$ is accepted. The appropriate use of virtual technology by government organizations (Beck, Pahlke and Seebach, 2014) will improve organizational performance (Daniel, Soto and Merigó, 2015; Acosta, Gabriel and Navarro, 2016), facilitating more effective control of fraud including corruption (Soomro et al., 2019). In addition, cyberspace also has a negative effect on crime space (Vahdati and Yasini, 2015), allowing the government to anticipate corruption with technology-based internal control systems such as whistleblowing system, gratification control unit, state officials wealth reporting applications (LHKSN and LHKPN), and others (Prihanto et al., 2020). Therefore, the role of information technology in government organizations is highly important to control corruption, manipulation of financial statements, policy violations, and ethical violations (Nawawi and Salin, 2018).

The results of the study also reveal a negative effect of information technology, thus $\mathrm{H} 4 \mathrm{a}$ is rejected. It is in line with the statement that the application of technology has a positive effect in developed countries, but it does not necessarily have similar effect in developing countries (Bierstaker, 2009; Kapoor, Zhou and Piramuthu, 2011; Sharma and Panigrahi, 2012; Chen et al., 2013; Kapardis, 2018) due to the fundamental differences that cannot be ignored. The importance of information technology in supporting governance should be empowered and optimized through guidance and management of information technology as part of governance (Erasmus and Marnewick, 2020). The role modern information technology (Halbouni, Obeid and Garbou, 2016b) is considerably beneficial to making strategic decisions and preventing information asymmetry (Lisic et al., 2014; Asmuni, Nawawi and Salin, 2015; Husnin, Nawawi and Salin, 2016) to achieve organizational goals (Einhorn, Marnewick and Meredith, 2019) and provide better public services.

\section{The effect of governance on corruption}

Governance has an insignificant effect on preventing corruption, thus $\mathrm{H} 5$ is rejected. It is not in line with the opinion that governance has an important role in preventing fraud (Halbouni, Obeid and Garbou, 2016a) from the point of view of Fraud Heptagon (Yusof, 2016) and avoiding fraud (Rubino and Vitolla, 2014), namely through effective organizational governance control mechanisms (Lisic et al., 2014). The government needs to strengthen the management and administration to reinforce independence in the future (Asmuni, Nawawi and Salin, 2015) to provide better service to the public. It is possible by increasing supervision on policies as well as training and monitoring (Frimpong, Andoh and Hene, 2016), even though supervision does not actually have an effective effect on preventing fraud (Siahaan, Umar and Br, 2019). To prevent and minimize corruption, the following strategic governance is necessary: regular employee rotation, regular audit, and wellimplemented government internal controls (Lisic et al., 2014; Prihanto et al., 2020). The issue of governance is that there are many rules, procedures, and bureaucracy that, rather than supporting, constrain the mobility of services, resulting in poor organizational performance (Tambun, 2020). Governance with numerous inadequate regulations has become an opening for officials and other parties to commit corruption, due to supply and demand that require each other and allow transactions to occur.

\section{CONCLUSION}

Referring to the results of the study, it is concluded that information technology has a direct significant effect on the prevention of corrupt behavior, while organizational culture, effective leadership, code of ethics, and governance have no 
significant effect on reducing the intention to commit corruption. Corruption occurs due to weak organizational culture, ineffective leadership, poorly-implemented code of ethics, and poor governance. The application of well-utilized technology can reduce corrupt behavior. The indirect effect is shown through the significant effect of organizational culture and code of ethics on the implementation of good governance. Leadership and information technology do not have a significant effect on governance and do not support good governance. Indirectly, leadership and technology do not affect governance because leaders have the potential to abuse and disobey the applied governance and commit deviations through access to existing technology information and various facilities as well authority entailed.

\section{REFERENCE}

Acosta, P. S., Gabriel, J. and Navarro, C. (2016) 'Guest editorial New ICTs for Knowledge Management in Organizations', Journal of Knowledge Management, 20(3).

Akbar, Y. H. and Vujić, V. (2014) 'Explaining corruption: The role of national culture and its implications for international management', Cross Cultural Management, 21(2), pp. 191218. doi: 10.1108/CCM-03-20130050.

Asmuni, A. I. ., Nawawi, A. and Salin, A. S. A. P. (2015) 'Ownership Structure and Auditor ' s Ethnicity of Malaysian Public Listed Companies', Social Sciences \& Humanities, 23(3), pp. 603622.

Copeland, M. K. (2015) 'The Importance of Ethics and Ethical Leadership in the Accounting Profession', Research on Professional Responsibility and Ethics in Accounting.

Daniel, P., Soto, A. P. and Merigó, J. M. (2015) 'Telematics and Informatics Analyzing the effects of technological , organizational and competition factors on Web knowledge exchange in SMEs', Telematics and Informatics,

32, pp. 23-32. doi: 10.1016/j.tele.2014.08.003.

Einhorn, F., Marnewick, C. and Meredith, J. (2019) 'International Journal of Project Management Achieving strategic bene fi ts from business IT projects: The critical importance of using the business case across the entire project lifetime', International Journal of Project Management, 37 (8), pp. 989-1002. doi: 10.1016/j.ijproman.2019.09.001.

Erasmus, W. and Marnewick, C. (2020) 'An IT governance framework for IS portfolio management', International Journal of Managing Projects in Business. doi: 10.1108/IJMPB-04-2020-0110.

Ferry, L. and Ahrens, T. (2016) 'Using management control to understand public sector corporate governance changes: localism, public interest, and enabling control in an English local authority', Journal of Accounting \& Organizational Change.

Frimpong, I. A., Andoh, C. and Hene, E. D. O. (2016) 'Causes, effects and deterrence of insurance fraud: evidence from Ghana', Journal of Financial Crime, 23(4), pp. 678-699. doi: 10.1108/JFC11-2015-0062.

Fung Jin, T. (2003) 'Analisis Faktor-Faktor Yang Mempengaruhi', Jurnal Bisnis Dan Akuntansi, 5(1), pp. 1-23.

Halbouni, S. S., Obeid, N. and Garbou, A. (2016a) 'Corporate governance and information technology in fraud prevention and detection', Managerial Auditing Journal, 31(6/7), pp. 589628. doi: 10.1108/MAJ-02-20151163.

Jumbe, M. and Proches, C. N. G. (2017) 'The impact of institutional culture on change initiatives in an electric utility company in Africa', African Journal of Economic and Management Studies, 7(3), pp. 295-313. doi: 10.1108/AJEMS-08-2015-0093.

Kapardis, M. K. (2018) 'Disentangling anticorruption agencies and accounting 
for their ineffectiveness', Journal of Financial Crime.

Khadijah, A. M. S., Kamaluddin, N. and Salin, A. S. A. P. (2015) 'Islamic Work Ethics ( IWE ) Practice among Employees of Banking Sectors', Middle-East Journal of Scientific Research, 23(5), pp. 924931.

doi:

10.5829/idosi.mejsr.2015.23.05.2217

3.

Komisi Pemberantasan Korupsi (2018) Sistem Pengendalian Internal, acch.kpk. Available at: https://acch.kpk.go.id/id/.

Lee, G. C. M. (2017) 'Police corruption: a comparison between China and India', Journal of Financial Crime.

Madril, O. (2020) 'Riset Pukat UGM: Aparat Pemerintah Terjerat Kasus Korupsi karena Aturannya Sendiri', Pukat Fakultas Hukum UGM.

Mandasari, R. (2019) 'Tata Kelola Pemerintahan Indonesia, Dipuji Perwakilan Negara Sahabat', rri.co.id, March.

Mashabi, S. (2020) 'ICW: Ada 169 Kasus Korupsi Sepanjang Semester I 2020'. Available at: https://nasional.kompas.com/read/2 020/09/29/16112851/icw-ada-169kasus-korupsi-sepanjang-semester-i2020.

Mensah, B. K. A. and Zutter, C. J. (2017) 'The relationship between corporate governance, corruption and forwardlooking information disclosure: a comparative study', Corporate Governance: The International Journal of Business in Society, 17(2), pp. 284304. doi: 10.1108/CG-11-2015-0150.

Nawawi, A. and Salin, A. S. A. P. (2018) 'Employee fraud and misconduct: empirical evidence from a telecommunication company', Information \& Computer Security, 26(1), pp. 129-144. doi: 10.1108/ICS07-2017-0046.

Nor, N. H. M., Nawawi, A. and Salin, A. S. A. P. (2018) 'The Impact of Audit Committee Independence and Auditor
Choice on Firms ' SOCIAL SCIENCES \& HUMANITIES The Impact of Audit Committee Independence and Auditor Choice on Firms ' Investment Level', Social Sciences \& Humanities, 26(3), pp. 1433-1454.

Omar, M., Nawaw, A. and Salin, A. S. A. P. (2016) 'The causes, impact and prevention of employee fraud - a case study of an automotive company', Journal of Financial Crime, 23(4).

Politis, J. D. and Politis, D. J. (2018) 'Examination of the relationship between servant leadership and agency problems: gender matters', Leadership \& Organization Development Journal, 39(2), pp. 170185. doi: 10.1108/LODJ-01-20160020.

Prabowo, H. Y. and Suhernita (2017) 'Be Like Water : Developing a Fluid Corruption Prevention Strategy', Journal of Financial Crime.

Prihanto, H. et al. (2020) 'How Indonesia Attempts to Prevent Corruption!', Oceanide, 12(2), pp. 70-85.

Prihanto, H. and Gunawan, I. D. (2020) 'Corruption in Indonesia (Is It Right to Governance, Leadership and It to Be Caused ?)', Journal of Economics and Sustainable Development, 11(2), pp. 56-65.

Prihanto, H. and Usmar (2020) 'Faktor Yang Menunjang Kualitas Pengadaan Barang Dan Jasa Pemerintah', Jurnal Akuntansi dan Binsis Indonesia, 1(2), pp. 71-82.

Rahim, S. A. A., Nawawi, A. and Salin, A. S. A. P. (2017) 'Internal control weaknesses in a cooperative body: Malaysian experience', Int. J. Management Practice, 10(2), pp. 131-151.

Robbins, S. P. and Coulter, M. (2012) Management, Eleventh Edition. United States of America: Pearson Education Limited.

Said, J. et al. (2017) 'Integrating ethical values into fraud triangle theory in assessing employee fraud: Evidence from the Malaysian banking industry', 
Journal of International Studies, 10(2), pp. 170-184. doi: 10.14254/20718330.2017/10-2/13.

Siahaan, M., Umar, H. and Br, R. (2019) 'Fraud Star Drives To Asset Misappropriation Moderated By Internal Controls', Journal of Southwest Jiaotong University, 54(4), pp. 1-10.

Siregar, S. V. and Tenoyo, B. (2015) 'Fraud awareness survey of private sector in Indonesia', Journal of Financial Crime, 22(3), pp. 329-346. doi: 10.1108/JFC03-2014-0016.

Soomro, Z. A. et al. (2019) 'Investigating identity fraud management practices in e-tail sector : a systematic review', Journal of Enterprise Information Management. doi: 10.1108/JEIM-062018-0110.

Sow, A. N. et al. (2018) 'Fraud prevention in Malaysian small and medium enterprises ( SMEs )', Journal of Financial Crime, 25(2), pp. 499-517. doi: 10.1108/JFC-05-2017-0049.

Steinbauer, R. et al. (2013) 'Ethical Leadership and Followers ' Moral Judgment: The Role of Followers ' Perceived Accountability and Selfleadership', Jounal Bus Ethics. doi: 10.1007/s10551-013-1662-x.

Sudarsa, A. G. (2019) 'Pembenahan Partai Politik sebagai Solusi Pemberantasan Korupsi', Kompas.com. Available at: https://www.kompas.com/tren/read /2019/12/09/220840365/pembena han-partai-politik-sebagai-solusipemberantasankorupsi?page $=3 . \% 0 \mathrm{~A}$.

Tambun, L. T. (2020) 'Jokowi: Masalah Tata Kelola Pemerintahan karena Banyak Aturan', Berita Satu, July. Available at: https://www.beritasatu.com/nasiona l/660045/jokowi-masalah-tatakelola-pemerintahan-karena-banyakaturan.

Vahdati, S. and Yasini, N. (2015) 'Computers in Human Behavior Factors affecting internet frauds in private sector: A case study in Cyberspace Surveillance and Scam Monitoring Agency of Iran $\mathrm{q}^{\prime}$, COMPUTERS IN HUMAN BEHAVIOR, 51, pp. 180-187. doi: 10.1016/j.chb.2015.04.058.

Vousinas, G. L. (2019) 'Elaborating on the theory of fraud. New theoretical extensions', Journal of Financial Crime, 26(1), pp. 1-17.

Wahab, E. A. A., Pitchay, A. A. and Ali, R. (2016) 'Culture, corporate governance and analysts forecast in Malaysia', Asian Review of Accounting, 23(3), pp. 232-255. doi: 10.1108/ARA-03-2014-0033.

Wolf, J. and Shelton, K. (2015) Seven Disciplines of a Leader. New Jersey: John Wiley \& Sons.

Yusof, K. M. (2016) Fraudulent Financial Reporting: An Application of Fraud Models to Malaysian Public Listed Companies Being a Thesis submitted for the Degree of Doctor of Philosophy in the University of Hull by Khairusany Mohamed Yusof B. Acc (Honours), Universiti Sain.

Zakaria, K. M., Anuar, N. and Salin, A. S. A. P. (2016) 'Internal controls and fraud empirical evidence from oil \& gas company', Journal of Financial Crime, 23(4). 